\title{
Metal accumulation in aquatic vegetation in heat- affected zone of Gusinoozersk state regional power plant
}

\author{
Valentina G. Shiretorova*, Svetlava V. Zhigzhitzhapova, Elena P. Dylenova, and \\ Larisa D. Radnaeva \\ Baikal Institute of Nature Management Siberian Branch of Russian Academy of Sciences, 670047, \\ Ulan-Ude, Russia
}

\begin{abstract}
The content of $\mathrm{Fe}, \mathrm{Mn}, \mathrm{Al}, \mathrm{Zn}, \mathrm{Ni}, \mathrm{Cu}, \mathrm{Pb}, \mathrm{Cr}, \mathrm{Cd}$ and $\mathrm{Hg}$ in higher aquatic plants, moss, charophyta and green filamentous algae was determined using inductively coupled plasma emission spectrometry. A comparative assessment of metal accumulation was conducted. Plants growing within the heat-affected zone of Gusinoozersk State Regional Power Plant, especially filamentous algae, contained the largest amount of metals, which indicates the higher pollution of water and sediments and intensification of metabolic processes and their accumulation in plants. It was shown that aquatic plants of Lake Gusinoe accumulated most of the studied metals in volumes greater than in other cooling reservoir of Siberia. Thus, this research provides one of the important steps for the development of regional environmental standards and environmental risk assessments.
\end{abstract}

\section{Introduction}

It is well-known that aquatic plants can intensively absorb macro- and microelements, organic substances, heavy metal ions and radionuclides, therefore they are used as one of the main objects of indication and monitoring of water quality, eutrophication and pollution of water bodies [1]. Aquatic plants play the leading energetic role of hydroecosystem's operation, thus, they determine the structure of biotic community of the water body.

Lake Gusinoe is the largest freshwater lake and one of the most important in water-related and fishing activities among water bodies of Transbaikalia [2]. The lake surface covers 164 $\mathrm{km}^{2}$. It has an average long of $24,8 \mathrm{~km}$, average width $-8 \mathrm{~km}, 15 \mathrm{~m}$ of average depth and 26 $\mathrm{m}$ of maximum depth. There is an anthropogenic impact exerted by Gusinoozersk State Regional Power Plant (Gusinoozersk SRPP), Kholboldzhinsky opencut coal mine, Gusinoozyorsk in the north-eastern part of the lake and the railway station with a wagon depot, Gusinoe Ozero village in the southwestern part. Gusinoozersk SRPP is the largest thermal power plant in Buryatia that takes $85.1 \%$ of the total water withdrawal of the Republic's surface waters. More than 600 million $\mathrm{m}^{3}$ of water from lake per year has been used for technical needs, which is $1 / 4$ of its volume. Such aquatic vegetation as Potamogeton L., Myriophyllum L., Fontinalis antipyretica Hedw., Chlorophyta and Chara spp. grow

\footnotetext{
* Corresponding author: vshiretorova@rambler.ru
} 
within the coastal part of the lake. Despite previously made research of metal accumulation in aquatic plants, their content in the plants of Lake Gusinoe has not been studied well enough.

The aim of the study was to determine the elemental composition of the most widespread higher aquatic plants of Lake Gusinoe: Potamogeton L. (P. pectinatus L. = Stuckenia pectinata (L.) Born., P. perfolatus L.), Myriophyllum L. (M. sibiricum Kom.), Fontinalis antipyretica Hedw., algae Chara spp. (Ch. inconnexa Allen., Ch. globularis Thuill.) and green filamentous (Chlorophyta). Also, the microelement composition of invasive species Elodea canadensis Michx. was analyzed.

\section{Material and methods}

Plant material was collected in July 2017-2019 without reference to the plant's age in different parts of Lake Gusinoe: 1 - the northern part, within the heat-affected zone of Gusinoozersk SRPP state regional power plant (near the zone of warm water discharge); 2 the southern part, within the housing-and-municipal pollution discharge zone of village Gusinoe Ozero; 3 - the eastern part. In the same sampling points the surface water and superficial sediment samples $(0-10 \mathrm{~cm})$ were collected. The samples of dried and crushed plant materials were decomposed with concentrated nitric acid using microwave digestion system MARS 6. Metal content was measured by inductively coupled plasma - optical emission spectrometry (ICP-OES) using a spectrometer with axial viewed plasma Profile Plus (Teledyne Leeman Labs, USA). The mercury content was determined by the cold steam method using a VP-100 hydride attachment to an atomic absorption spectrophotometer Solaar M6 (Thermo Scientific, USA).

\section{Results and discussion}

Plants, growing within the zone of warm water discharge of Gusinoozersk SRPP, are characterized by increasing concentration of all studied metals in comparison with other sampling points (Fig. 1), which may indicate an intensification of metabolic processes and their accumulation in plants. The water and sediments metal content (Table 1) is also highest in this part of the lake. Plants growing in the warm water discharge zone of the Gusinoozerskaya SRPP are characterized by an increased content of all studied metals in comparison with other sampling points (Fig. 1), which may indicate an increase in metabolic processes and their accumulation in plants. The content of metals in water and bottom sediments (Table 1) is also the highest in this part of the lake. The influx of metals into this part of the lake occurs due to the washout by melt water and filtration of atmospheric precipitation through ash dumps and dumps of coal mining enterprises located on the coastal territory, as well as with drainage (quarry, mine) waters. In addition, due to atmospheric transport, a significant amount of atmospheric emissions from the state district power station from coal combustion, which also include heavy metals, falls on the lake water area [3]. The intensive and year-round process of growth of aquatic vegetation in the area of warm water discharge of the Gusinoozerskaya SRPP contributes to the accumulation of metals in the bottom sediments of this part of the lake. Lower values are found in the southern and eastern parts of the lake. Differences in the content of metals in lake water depending on the sampling site are less pronounced, especially for metals with a low content. This is due to the complete wind mixing of the water mass, which is characteristic of Lake Gusinoe. The intense and allyear-round process of aquatic vegetation growth near the area of Gusinoozersk SRPP promotes metals accumulation in the bottom sediments of this part of the lake. The lower values were determined in the southern and eastern parts of the lake. Differences in the 
content of metals in lake water depending on the sampling site are less pronounced, especially for metals with a low content. This is due to the complete wind mixing of the water mass, which is characteristic of Lake Gusinoe.
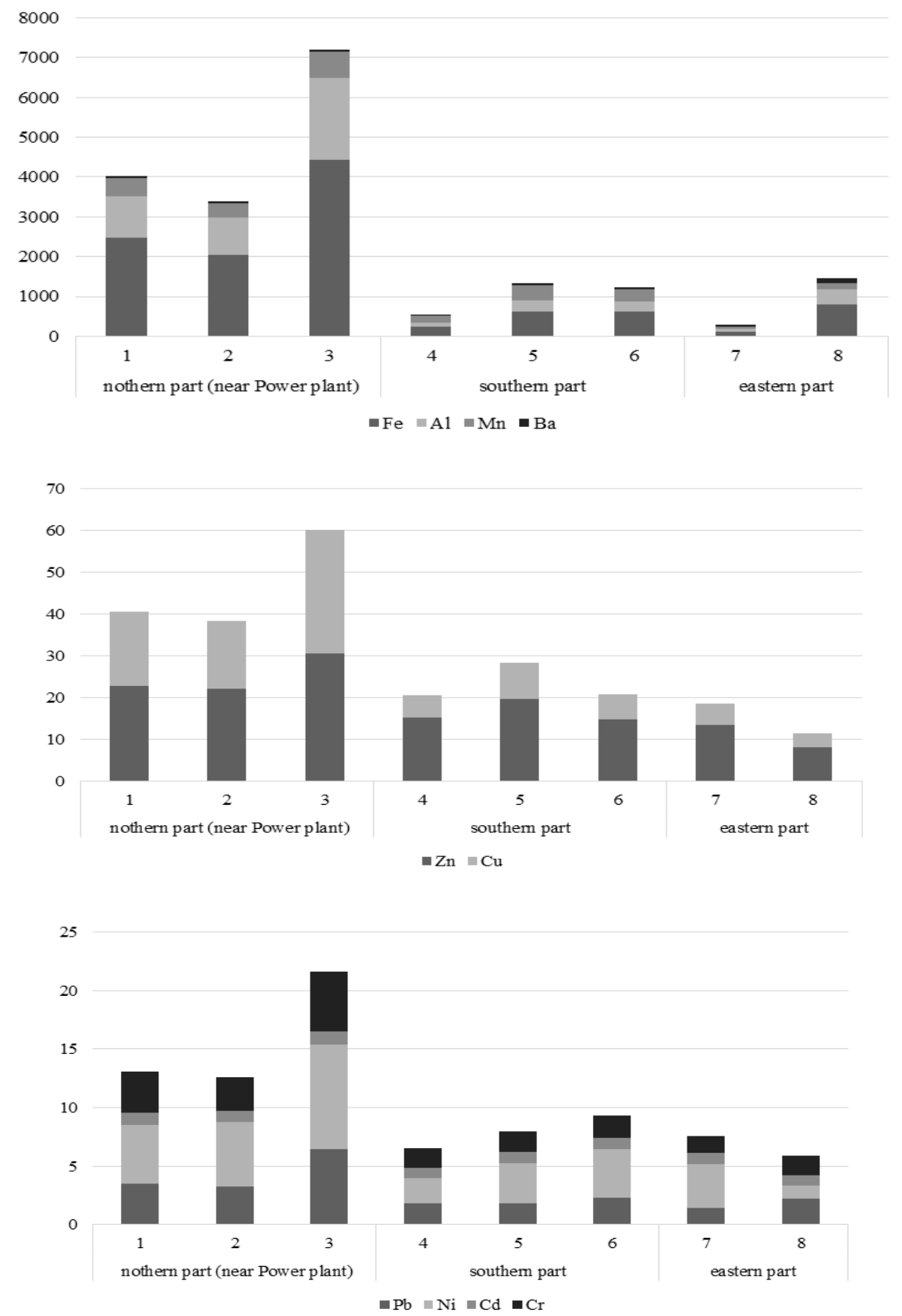

Fig 1. The content of metals in aquatic plants from different parts of Lake Gusinoe, $\mathrm{mg} / \mathrm{kg}$ of dry weight. 1, 4 - Myriophyllum L., 2 - Elodea, 3 - green filamentous algae (Chlorophyta), 5, 7 Potamogeton L., 8 - water moss.

Table 1. The content of metals in water and sediments of lake Gusinoe. 


\begin{tabular}{|l|c|c|c|c|c|c|}
\hline \multirow{2}{*}{ Metal } & \multicolumn{3}{|c|}{ Surface water, mg/l } & \multicolumn{3}{c|}{ Sediments, $\mathrm{mg} / \mathrm{kg}$ (dry weigh) } \\
\cline { 2 - 7 } & $1 *$ & 2 & 3 & 1 & 2 & 3 \\
\hline $\mathrm{Al}$ & 0.021 & 0.008 & 0.007 & 3037 & 1249 & 1067 \\
\hline $\mathrm{Fe}$ & 0.031 & 0.007 & 0.006 & 7610 & 1583 & 1089 \\
\hline $\mathrm{Mn}$ & 0.009 & 0.002 & 0.001 & 351.4 & 147.2 & 59.7 \\
\hline $\mathrm{Zn}$ & 0.086 & 0.045 & 0.023 & 82.11 & 23.18 & 24.59 \\
\hline $\mathrm{Cu}$ & 0.007 & 0.001 & 0.001 & 17.29 & 2.87 & 1.92 \\
\hline $\mathrm{Pb}$ & 0.002 & 0.001 & 0.002 & 15.07 & 12.35 & 9.72 \\
\hline $\mathrm{Cd}$ & 0.001 & 0.001 & 0.001 & 0.61 & 0.47 & 0.15 \\
\hline $\mathrm{Ni}$ & 0.001 & 0.001 & 0.001 & 7.33 & 3.02 & 1.40 \\
\hline $\mathrm{Cr}$ & 0.002 & 0.001 & 0.001 & 11.76 & 7.51 & 7.87 \\
\hline $\mathrm{Hg}$ & n.d. $* *$ & n.d. & n.d. & 0.35 & 0.11 & 0.04 \\
\hline
\end{tabular}

* 1 - northern part (near Power plant), 2 - sothern part, 3 - eastern part

** n.d. - not detected

The absolute maximum values of $\mathrm{Al}, \mathrm{Fe}, \mathrm{Cu}, \mathrm{Zn}, \mathrm{Mn}, \mathrm{Pb}, \mathrm{Cd}, \mathrm{Cr}$ contents were observed in filamentous algae samples. This fact is corresponded to the literature data that shows the ability of filamentous algae to accumulate elements in large amounts, and their use for bioremediation [4]. The following sequence of metal accumulation in aquatic plants collected in the zone of warm water discharge from Gusinoozersk SRPP and in the north-eastern part of Lake Gusinoe was observed: $\mathrm{Fe}>\mathrm{Al}>\mathrm{Mn}>\mathrm{Ba}>\mathrm{Zn}>\mathrm{Cu}>\mathrm{Ni}>\mathrm{Pb}>\mathrm{Cr}>\mathrm{Cd}>\mathrm{Hg}$ (in Chara algae: $\mathrm{Fe}>\mathrm{Al}>\mathrm{Mn}>\mathrm{Ba}>\mathrm{Zn}>\mathrm{Cu}>\mathrm{Pb}>\mathrm{Ni}>\mathrm{Cr}>\mathrm{Cd}>\mathrm{Hg}$ ). Plants collected in the southern part of the lake, which has anthropogenic influence of Gusinoe Ozero village, the metal content decreases in the following sequence: $\mathrm{Fe}>\mathrm{Mn}>\mathrm{Al}>\mathrm{Ba}>\mathrm{Zn}>\mathrm{Cu}>\mathrm{Ni}>\mathrm{Pb}>\mathrm{Cr}>\mathrm{Cd}>$ $\mathrm{Hg}$, in water mosses $\mathrm{Fe}>\mathrm{Mn}>\mathrm{Al}>\mathrm{Ba}>\mathrm{Zn}>\mathrm{Ni}>\mathrm{Cu}>\mathrm{Pb}>\mathrm{Cr}>\mathrm{Cd}>\mathrm{Hg}$.

As there is no confirmed maximum permissible concentration (MPC) for metals contained in aquatic plants, heavy metals' pollution of the water body can be estimated by comparing detected concentrations in other aquatic ecosystems of Siberia of the same objects. The content of aluminum, copper, zinc, nickel, chromium in Myriophyllum L. and Potamogeton L. of Lake Gusinoe was lower, while iron, zinc (in the area of warm water discharge of Gusinoozersk SRPP) and lead concentrations were higher than in Potamogeton L. from Bugach reservoir (Krasnoyarsk Territory) [5]. The content of all mentioned elements is higher in aquatic plants of Lake Gusinoe than in Potamogeton L. from Lake Kenon - the cooling reservoir of thermal power plant (TPP) (Trans-Baikal Territory) [6]. The content of super-toxicant - mercury in the studied aquatic plants $(0.04-0.12 \mathrm{mg} / \mathrm{kg})$ was comparable to the concentration of mercury in the plants of Bratsk reservoir - water body with high mercury pollution [7].

\section{Conclusion}

Plants growing within the heat-affected zone of Gusinoozersk State Regional Power Plant, especially filamentous algae, contained the largest amount of metals, which indicates the higher pollution of water and sediments and intensification of metabolic processes and their accumulation in plants. The sources of metals entering this part of the lake are ash dumps and dumps of coal mining located in the coastal part, as well as atmospheric emissions from burning coal from the state district power station. It was shown that aquatic plants of Lake Gusinoe accumulated most of the studied metals in volumes greater than in other cooling reservoir of Siberia. Obtained data of the elemental composition expanded the understanding of the biochemical characteristics of aquatic plants and the possibilities of their use for 
monitoring the state of water bodies. Thus, this research provides one of the important steps for the development of regional environmental standards and environmental risk assessments.

This research was conducted in the framework of the State assignment of Baikal Institute of Nature Management, and with partial financial support of the Grant № 075-15-2020-787 in the form of a subsidy for a Major scientific project from Ministry of Science and Higher Education of Russia (Project "Fundamentals, methods and technologies for digital monitoring and forecasting of the environmental situation on the Baikal natural territory").

\section{References}

1. A.F. Titov, N.M. Kaznina, V.V. Talanova. Heavy metals and plants (Karelian Scientific Center of the Russian Academy of Sciences, 2014)

2. I.M. Borisenko, N.M. Pronin, B.B. Shaybonov et al., Ecology of Lake Gusinoe (Buryat Scientific Center SB RAS, 1994)

3. A.A. Fadova, G.V. Kucherik, E.V. Zablotskaya, Power plants and technologies, 6 (2), 138-145 (2020)

4. A.P. Kuklin, Int. J. Appl. \& Fundam. Res., 3, 85-88 (2017)

5. E.A. Ivanova, O. V. Anischenko, I. V. Gribovskaya et al., Siberian J. of Ecology, 19 (4), 485-495 (2012)

6. G.Ts. Tsybekmitova, A.P. Kuklin, N.A. Tashlykova et al., Novosib. State Pedagog. Univ. Bull., 7 (3), 194-209 (2017)

7. M.G. Azovsky, M.V. Pastukhov, V.I. Grebenshchikova, Water: Chemistry and ecology, 8, 20-24 (2010) 